\title{
Study of Genetic Parameters for Water Use Efficiency Traits, Yield and Yield Attributes in Groundnut (Arachis hypogaea L.)
}

\author{
K. John", M. V. Madhavi Santhoshi and P. Rajasekhar
}

Institute of Frontier Technology, Regional Agricultural Research Station, Acharya N.G. Ranga Agricultural University, Tirupati-517502, Andhra Pradesh, India

*Corresponding author

\begin{tabular}{|l|}
\hline Ke y w o r d s \\
Genetic variability, \\
Water use \\
efficiency, \\
Heritability, \\
Genetic advance \\
\hline Article Info \\
\hline $\begin{array}{l}\text { Accepted: } \\
\text { 12 November } 2019 \\
\text { Available Online: } \\
\text { 10 December } 2019\end{array}$ \\
\hline
\end{tabular}

\section{Introduction}

Groundnut (Arachis hypogaea L.) is a highly self pollinated crop and can be grown successfully in tropical and subtropical areas. Groundnut is the important oilseed crop of India. Though it leads in area and production in the world its productivity is low due to various abiotic and biotic stresses. Further, pod yield besides physiological traits in groundnut are quantitatively inherited complex traits and is highly influenced by environment. Drought is the most important factor limiting the yield potential of the rainfed crop. Although high yield potential is the target of most crop breeding programs, it 
might not be compatible with superior drought resistance. On the other hand, high yield potential can contribute to yield in moderate stress environments. The crop has narrow genetic base therefore, it is essential to create more variability in the segregating materials. Genetic variability is the basic requirement for crop improvement as it provides wider scope for selection. Thus, effectiveness of selection is dependent upon the nature, extent and magnitude of genetic variability present in the material and the extent to which it is heritable (Chavadhari et al., 2017). The genetic variability has to be looked into for planning suitable measures for the crop improvement. Crop physiologists have identified a number of traits that would help the breeder in development and identification of moisture stress tolerant genotypes with high yield potential (Basu et al.,2004).

Water use efficiency is one such important trait which is correlated with specific leaf area. SPAD chlorophyll meter reading (SCMR) and photosynthetic rate and these traits have been suggested as surrogate traits in selecting for water use efficiency in groundnut (Nandini et al., 2011). The genetic variability has to be looked into for planning breeding approaches for the crop improvement. This necessitates a thorough knowledge of variability owing to genetic factors, actual genetic variation heritable in the progeny and the genetic advance that can be achieved through selection (Shinde et al., 2010).

The observed variability is a combined measure of genetic and environmental causes (Patel et al., 2009). In genetic studies, characters with high genotypic coefficient of variation indicate the potential for an effective selection (Sadiq et al., 1986). Wadikar et al., (2018) observed high heritability coupled with high genetic advance as per cent of mean for kernel yield per plant, number of pods per plant and pod yield per plant. Thus, effectiveness of selection is dependent upon the nature, extent and magnitude of genetic variability present in material and the extent to which it is heritable. In the present study, variability and other genetic parameters were studied for yield and yield attributes for efficient selection.

\section{Materials and Methods}

Forty three genotypes were sown in a Randomised Block Design (RBD) with two replications during rabi 2017-18. Each genotype was sown in 3 rows of $5 \mathrm{~m}$ length. All the 43 genotypes were allotted at random to the experimental plots in each replication. Observations were recorded on five random plants in each genotype per replication. The data were recorded for plant height $(\mathrm{cm})$, number of primary branches per plant, number of secondary branches per plant, specific leaf area, SAPD Chlorophyll meter reading, number of well-filled and mature pods per plant, number of immature pods per plant, 100- pod weight (g), 100- kernel weight (g), sound mature kernel per cent, dry haulms yield per plant $(\mathrm{g})$ and pod yield per plant $(\mathrm{g})$. The data was analyzed statistically and genetic parameters viz., Phenotypic and Genotypic coefficients of variation (PCV and GCV) were computed according to the Burton (1952). Heritability in broad sense was estimated using the formula of Allard (1960). Genetic advance (GA) was calculated as per the formula as suggested by Johnson et al., (1955).

\section{Results and Discussion}

\section{Mean performance of groundnut genotypes}

Mean performance of all the genotypes for the characters viz., plant height, number of primary branches per plant, number of secondary branches per plant, specific leaf area, SAPD Chlorophyll meter reading, 
number of well-filled and mature pods per plant, number of immature pods per plant, 100- pod weight (g), 100- kernel weight (g), sound mature kernel per cent, dry haulms yield per plant $(\mathrm{g})$ and pod yield per plant $(\mathrm{g})$. are presented hereunder (Table 1).

The plant height varied from $18.9 \mathrm{~cm}$ (TCGS 1876 ) to $45.5 \mathrm{~cm}$ (TCGS-1805). The mean height of the genotypes was $28.5 \mathrm{~cm}$. The genotypes viz., TCGS-1514, TCGS-1516, TCGS-1520, TCGS-1521, TCGS-1522, TCGS-1523, TCGS-1527, TCGS-TCGS1805, TCGS-1810, TCGS-1813, TCGS-1814, TCGS-1815, TCGS-1816, TCGS-1817, TCGS-1818, TCGS-1819, TCGS-1820, TCGS-1821, TCGS-1822, TCGS-1824, TCGS-1831, TCGS-1837, TCGS-1838, TCGS-1845, TCGS-1851, TCGS-1855, TCGS-1868, TCGS-1869, Greeshma, Dharani and Narayani recorded higher valves for the Plant height than the general mean.

The maximum number of primary branches per plant was recorded in ICGV-07262 (10.4) where as it was the lowest in Greeshma (3.5) with general mean of 5.9 branches per plant. Fifteen genotypes viz., TCGS-1523, TCGS1527, TCGS-1529, TCGS-1804, TCGS-1814, TCGS-1816, TCGS-1819, TCGS-1837, TCGS-1838, TCGS-1839, TCGS-1845, TCGS-1855, TCGS-1869, TCGS-1876, and ICGV-07262 possessed higher number of primary branches per plant among the genotypes. The maximum number of secondary branches per plant was recorded in TCGS-1527 (7.3) where as it was the lowest in TCGS-1824 (0.1) with general mean of 1.4 branches per plant. Twenty genotypes viz., TCGS-1514, TCGS-1520, TCGS-1523, TCGS-1527, TCGS-1529, TCGS-1805, TCGS-1809, TCGS-1815, TCGS-1816, TCGS-1819, TCGS-1831, TCGS-1838, TCGS-1839, TCGS-1845, TCGS-1851, TCGS-1855, TCGS-1869, TCGS-1872, TCGS-1876 and ICGV-07262 recorded more number of secondary branches than general mean

The mean specific leaf area (SLA) at 60 DAS ranged from $163.2 \mathrm{~cm}^{2} \mathrm{~g}^{-1}$ (TCGS-1821) to 265.4 (TCGS-1825). Nineteen genotypes viz., TCGS-1520, TCGS-1522, TCGS-1527, TCGS-1805, TCGS-1813, TCGS-1814, TCGS-1815, TCGS-1816, TCGS-1817, TCGS-1820, TCGS-1824, TCGS-1825, TCGS-1829, TCGS-1831, TCGS-1838, TCGS-1853, TCGS-1868, TCGS-1871 and TCGS-1872 exceeded the general mean of 219. SPAD chlorophyll meter reading (SCMR) at 60 DAS ranged from 39.50 (TCGS-1876) to 49.60 (TCGS-1523) with a general mean of 42 . The SPAD chlorophyll meter reading of thirty genotypes viz., TCGS1514, TCGS-1516, TCGS-1520, TCGS-1521, TCGS-1522, TCGS-1523, TCGS-1527, TCGS-1529, TCGS-1804, TCGS-1805, TCGS-1807, TCGS-1809, TCGS-1810, TCGS-1813, TCGS-1815, TCGS-1818, TCGS-1819, TCGS-1821, TCGS-1822, TCGS-1824, TCGS-1825, TCGS-1829, TCGS-1831, TCGS-1837, TCGS-1839, TCGS-1851, TCGS-1853, TCGS1855,TCGS-1871, ICGV-07262 and Greeshma exceeded the general mean.

Number of well-filled and mature pods per plant ranged from 7.8 (TCGS-1869) to 45.0 (TCGS-1835) with a general mean of 13. Thirty nine genotypes recorded high values over the general mean for number of wellfilled and mature pods per plant. Number of immature pods per plant ranged from 1.7 (TCGS-1819 and TCGS-1813) to 6.3 (TCGS1853 ) with a general mean of 3 . Twenty one genotypes viz., TCGS-1520, TCGS-1521, TCGS-1809, TCGS-1813, TCGS-1816, TCGS-1817, TCGS-1818, TCGS-1819, TCGS-1820, TCGS-1822, TCGS-1829, TCGS-1831, TCGS-1837, TCGS-1855, TCGS-1868, TCGS-1869, TCGS1871,TCGS-1872, Greeshma, Dharani and 
Narayani recorded low values than the general mean for recorded low values than the general mean for number of immature pods per plant

Mean 100-pod weight (g) ranged from 62.0g (Dharani) to $104.7 \mathrm{~g}$ (TCGS-1807) with a general mean of $81.2 \mathrm{~g}$. The genotypes viz., TCGS-1514, TCGS-1516, TCGS-1520, TCGS-1521, TCGS-1523, TCGS-1804, TCGS-1805, TCGS-1807, TCGS-1814, TCGS-1815, TCGS-1818, TCGS-1819, TCGS-1821, TCGS-1822, TCGS-1824, TCGS-1825, TCGS-1837, TCGS-1838, TCGS-1839, TCGS-1845, TCGS-1868, TCGS-1871, TCGS-1872,TCGS-1876 and Greeshma exceeded the general mean.

Mean shelling percent significantly varied from $61.7 \%$ (TCGS-1817) to $74.3 \%$ (Dharani) with a general mean of $67.4 \%$. Fourteen genotypes viz., TCGS-1520, TCGS-1522, TCGS-1523, TCGS-1527, TCGS-1829, TCGS-1814, TCGS-1819, TCGS-1824, TCGS-1825 TCGS-1845, TCGS-1868, TCGS-1876, Greeshma and Dharani exceeded the general mean.

Mean 100-kernel weight ranged from $26.7 \mathrm{~g}$ (TCGS-1522) to $44.7 \mathrm{~g}$ (TCGS-1537) with the general mean $34.8 \mathrm{~g}$. Twenty three genotypes viz., TCGS-1514, TCGS-1516, TCGS-1520, TCGS-1527, TCGS-1529, TCGS-1804, TCGS-1805, TCGS-1807, TCGS-1809, TCGS-1815, TCGS-1816, TCGS-1817, TCGS-1818, TCGS-1820, TCGS-1824, TCGS-1825, TCGS-1839, TCGS-1845, TCGS-1851, TCGS-1853, TCGS-1868, Greeshma and Dharani recorded more number of 100-kernel weight than general mean.

Mean SMK per cent among ranged from $85.2 \%$ (TCGS-1818) to 95.8\% (TCGS-1818) with the general mean $90.2 \%$. Twenty one genotypes viz., TCGS-1514, TCGS-1516, TCGS-1523, TCGS-1805, TCGS-1809, TCGS-1815, TCGS-1818, TCGS-1820,
TCGS-1821, TCGS-1822, TCGS-1831, TCGS-1837, TCGS-1838, TCGS-1839, TCGS-1845, TCGS-1851, TCGS-1855, TCGS-1868, TCGS-1872, Greeshma and Narayani recorded more Sound mature kernel per cent than the general mean.

The range of variation for mean pod yield per plant was between 4.0g (TCGS-1869) and $31.2 \mathrm{~g}$ (TCGS-1514) and with the general mean 14.3g. The genotypes viz., TCGS-1514, TCGS-1516, TCGS-1521, TCGS-1522, TCGS-1523, TCGS-1527, TCGS-1529, TCGS-1805, TCGS-1807, TCGS-1810, TCGS-1814, TCGS-1815, TCGS-1816, TCGS-1818, TCGS-1819, TCGS-1820, TCGS-1821, TCGS-1822, TCGS-1824, TCGS-1825, TCGS-1831, TCGS-1837, TCGS-1838, TCGS-1839, TCGS-1845, TCGS-1851, TCGS-1853, TCGS-1855 and TCGS-1868 recorded higher values for pod yield per plant than general mean.

\section{Genetic parameters}

\section{Genotypic (GCV) and phenotypic (PCV) coefficients of variation}

The analysis of variance revealed significant differences were observed for all the traits studied. The results are presented in the Tables 2 and 3.

The estimates of genotypic and phenotypic coefficients of variability indicated that the values of PCV were higher than the GCV suggesting the influence of environmental factors.

Less difference was observed between PCV and GCV in certain cases indicated that these characters were less influenced by the environment. Similar results were reported by. Similar results were reported by John et al., (2006), Korat et al., (2009) and Ladole et al., (2009). 
Table.1 Mean performance of groundnut genotypes for water use efficiency traits, yield and yield attributes

\begin{tabular}{|c|c|c|c|c|c|c|c|c|c|c|c|c|c|}
\hline S.No. & Genotypes & $\mathrm{PH}$ & $\mathrm{PB}$ & SB & SLA & SCMR & MP & IM P & $100 \mathrm{PWT}$ & S P & $100 \mathrm{KWT}$ & SMK \% & PY \\
\hline 1 & TCGS-1514 & 35.7 & 5.1 & 2.7 & 197.6 & 46.6 & 16.4 & 4.1 & 103.3 & 64.3 & 41.0 & 90.4 & 31.2 \\
\hline 2 & TCGS-1516 & 41.4 & 4.3 & 1.2 & 185.6 & 48.3 & 102.7 & 4.3 & 96.0 & 66.3 & 42.0 & 91.6 & 23.6 \\
\hline 3 & TCGS-1520 & 29.3 & 6.2 & 4.9 & 230.6 & 42.9 & 14.7 & 2.5 & 84.3 & 71.0 & 36.3 & 88.0 & 12.2 \\
\hline 4 & TCGS-1521 & 34.5 & 5.5 & 1.3 & 210.4 & 43.9 & 21.3 & 3.4 & 86.0 & 67.0 & 32.3 & 89.3 & 22.8 \\
\hline 5 & TCGS-1522 & 36.8 & 4.2 & 0.6 & 222.0 & 44.6 & 27.1 & 3.1 & 66.7 & 71.7 & 26.7 & 89.9 & 27.8 \\
\hline 6 & TCGS-1523 & 39.9 & 10.3 & 5.7 & 193.3 & 49.6 & 27.2 & 4.6 & 80.0 & 72.7 & 34.0 & 92.8 & 28 \\
\hline 7 & TCGS-1527 & 31.4 & 10.2 & 7.3 & 231.0 & 45.1 & 25.3 & 3.6 & 77.7 & 70.7 & 35.3 & 88.2 & 28.4 \\
\hline 8 & TCGS-1529 & 27.7 & 6.4 & 3.5 & 206.2 & 46.8 & 22.2 & 3.7 & 81.0 & 69.7 & 35.7 & 90.0 & 18 \\
\hline 9 & TCGS-1804 & 27.7 & 6.2 & 0.4 & 218.2 & 46.9 & 17.7 & 3.1 & 93.3 & 62.3 & 36.3 & 88.7 & 13.4 \\
\hline 10 & TCGS-1805 & 45.5 & 5.6 & 3.7 & 254.6 & 44.5 & 16.8 & 3.2 & 85.7 & 62.3 & 37.0 & 91.0 & 17.6 \\
\hline 11 & TCGS-1807 & 27.8 & 5.1 & 0.6 & 207.5 & 43.4 & 14.3 & 5.3 & 104.7 & 66.3 & 42.7 & 90.1 & 15.6 \\
\hline 12 & TCGS-1809 & 27.4 & 5.0 & 1.7 & 204.1 & 44.2 & 13.6 & 2.0 & 80.3 & 65.0 & 35.0 & 91.5 & 10.0 \\
\hline 13 & TCGS-1810 & 30.6 & 4.6 & 1.1 & 231.7 & 42.1 & 14.6 & 3.6 & 71.0 & 67.0 & 30.7 & 85.9 & 15.4 \\
\hline 14 & TCGS-1813 & 28.7 & 4.2 & 0.9 & 228.4 & 42.5 & 13.0 & 1.7 & 80.0 & 62.3 & 28.3 & 88.1 & 7.6 \\
\hline 15 & TCGS-1814 & 31.2 & 7.7 & 0.9 & 244.4 & 40.9 & 17.9 & 3.6 & 84.0 & 71.0 & 33.7 & 85.2 & 18.2 \\
\hline 16 & TCGS-1815 & 40.3 & 5.6 & 2.9 & 239.6 & 43.9 & 21.0 & 3.7 & 85.3 & 62.7 & 37.7 & 91.6 & 20.6 \\
\hline 17 & TCGS-1816 & 37.0 & 6.8 & 1.7 & 242.4 & 41.2 & 17.4 & 2.9 & 74.7 & 65.0 & 36.0 & 85.7 & 17.6 \\
\hline 18 & TCGS-1817 & 29.7 & 4.9 & 0.5 & 256.1 & 40.4 & 13.7 & 2.6 & 71.7 & 61.7 & 38.3 & 88.3 & 10.6 \\
\hline 19 & TCGS-1818 & 35.4 & 5.3 & 1.5 & 218.9 & 44.8 & 17.2 & 2.2 & 88.7 & 65.7 & 36.3 & 95.8 & 14.8 \\
\hline 20 & TCGS-1819 & 40.3 & 5.8 & 1.8 & 192.6 & 45.0 & 15.4 & 1.7 & 88.3 & 70.7 & 33.7 & 88.4 & 19.6 \\
\hline 21 & TCGS-1820 & 30.7 & 4.6 & 0.9 & 227.6 & 41.3 & 21.5 & 2.7 & 79.0 & 68.3 & 38.0 & 91.2 & 20.8 \\
\hline 22 & TCGS-1821 & 34.5 & 4.4 & 1.3 & 163.2 & 44.8 & 16.7 & 3.3 & 91.0 & 66.0 & 32.3 & 91.6 & 18.6 \\
\hline 23 & TCGS-1822 & 29.2 & 5.3 & 0.7 & 218.8 & 44.4 & 18.7 & 2.7 & 97.0 & 68.7 & 30.0 & 90.6 & 22.4 \\
\hline 24 & TCGS-1824 & 37.4 & 5.1 & 0.1 & 236.2 & 43.8 & 18.3 & 3.5 & 83.0 & 72.0 & 39.7 & 90.7 & 19.8 \\
\hline 25 & TCGS-1825 & 27.0 & 4.9 & 0.4 & 265.4 & 44.8 & 13.7 & 3.4 & 92.0 & 71.0 & 40.0 & 89.5 & 14.4 \\
\hline 26 & TCGS-1829 & 27.4 & 4.1 & 0.6 & 204.1 & 44.9 & 10.8 & 2.7 & 76.7 & 68.3 & 32.7 & 90.1 & 10.8 \\
\hline 27 & TCGS-1831 & 32.3 & 5.2 & 2.1 & 201.4 & 44.9 & 16.9 & 2.9 & 78.3 & 66.0 & 33.7 & 91.2 & 17.4 \\
\hline 28 & TCGS-1837 & 37.1 & 6.2 & 1.2 & 188.2 & 47.5 & 45.0 & 2.5 & 101.3 & 68.7 & 44.7 & 91.0 & 30.2 \\
\hline 29 & TCGS-1838 & 36.7 & 8.1 & 3.7 & 222.4 & 40.5 & 24.5 & 4.2 & 83.7 & 64.7 & 34.7 & 91.2 & 26.8 \\
\hline 30 & TCGS-1839 & 28.4 & 7.3 & 3.2 & 217.1 & 48.8 & 25.4 & 4.2 & 102.7 & 66.0 & 42.3 & 90.6 & 26 \\
\hline 31 & TCGS-1845 & 32.7 & 6.2 & 2.3 & 213.4 & 41.0 & 21.7 & 5.2 & 89.3 & 70.0 & 34.7 & 91.4 & 26.6 \\
\hline 32 & TCGS-1851 & 29.3 & 5.5 & 2.5 & 205.9 & 43.1 & 22.4 & 4.4 & 76.7 & 67.3 & 37.7 & 90.7 & 24.0 \\
\hline 33 & TCGS-1853 & 28.3 & 4.7 & 0.9 & 223.6 & 44.5 & 17.4 & 6.2 & 75.0 & 66.3 & 35.3 & 85.2 & 17.2 \\
\hline 34 & TCGS-1855 & 35.3 & 7.0 & 4.2 & 200.4 & 43.4 & 24.8 & 2.9 & 77.3 & 65.7 & 34.0 & 91.0 & 29.0 \\
\hline 35 & TCGS-1868 & 44.5 & 4.6 & 0.6 & 228.5 & 41.8 & 21.8 & 2.8 & 85.7 & 74.3 & 37.7 & 91.7 & 21.6 \\
\hline 36 & TCGS-1869 & 30.1 & 8.7 & 2.9 & 217.6 & 41.7 & 7.8 & 2.7 & 70.0 & 64.7 & 29.0 & 88.8 & 4.0 \\
\hline 37 & TCGS-1871 & 23.2 & 6.5 & 0.8 & 220.8 & 43.1 & 9.1 & 2.1 & 94.3 & 64.7 & 38.0 & 89.8 & 10.0 \\
\hline 38 & TCGS-1872 & 19.9 & 5.0 & 1.4 & 240.3 & 41.7 & 13.5 & 2.3 & 86.7 & 66.3 & 34.7 & 92.6 & 9.2 \\
\hline 39 & TCGS-1876 & 18.9 & 8.1 & 4.2 & 235.9 & 39.5 & 14.2 & 2.8 & 86.3 & 71.7 & 33.0 & 87.3 & 11.0 \\
\hline 40 & ICGV-07262 & 23.7 & 10.4 & 4.1 & 195.8 & 44.2 & 14.9 & 3.8 & 77.7 & 64.0 & 29.7 & 90.0 & 10.4 \\
\hline 41 & Greeshma & 29.6 & 3.5 & 0.2 & 204.7 & 42.0 & 12.6 & 2.7 & 90.3 & 69.7 & 40.3 & 93.9 & 11.2 \\
\hline 42 & Dharani & 33.9 & 4.1 & 0.6 & 234.6 & 41.5 & 15.7 & 2.6 & 62.0 & 69.7 & 35.0 & 85.4 & 13.8 \\
\hline \multirow[t]{2}{*}{43} & Narayani & 30.2 & 4.8 & 0.2 & 208.2 & 41.7 & 15.1 & 2.5 & 74.0 & 63.3 & 28.3 & 91.2 & 11.6 \\
\hline & General mean & 28.5 & 5.9 & 1.4 & 219.0 & 42.0 & 13.0 & 3.0 & 81.2 & 67.4 & 34.8 & 90.2 & 14.3 \\
\hline
\end{tabular}

PLHT : Plant height NPBPP : Number of primary branches per plant SLA : Specific leaf area SCMR : SAPD Chlorophyll meter reading

NIPPP : Number of immature pods per plant $\quad 100$ PWT $: 100$ pod weight $(\mathrm{g})$,

SMK: Sound mature kernel per cent
DHY: Dry haulms yield per plant $(\mathrm{g})$
NSBPP: Number of secondary branches per plant NMPP : Number of well-filled and mature pods per plant $100 \mathrm{KWT}$ : 100 kernel weight (g)

PYPP : Pod yield per plant $(\mathrm{g})$ 
Table.2 Estimates of genetic parameters for water use efficiency traits, yield and yield attributes in groundnut

\begin{tabular}{|c|c|c|c|c|c|c|c|c|c|c|c|c|c|c|}
\hline \multirow{2}{*}{\multicolumn{2}{|c|}{$\begin{array}{c}\text { Genetic } \\
\text { parameter/Character }\end{array}$}} & \multirow{3}{*}{$\begin{array}{c}\begin{array}{c}\text { PLHT } \\
(\mathbf{c m})\end{array} \\
34.5\end{array}$} & \multirow{3}{*}{\begin{tabular}{|c|} 
NPBPP \\
2.7 \\
\end{tabular}} & \multirow{3}{*}{\begin{tabular}{|c|} 
NSBPP \\
2.5 \\
\end{tabular}} & \multicolumn{2}{|c|}{$\begin{array}{l}\text { Water use } \\
\text { efficiency traits }\end{array}$} & \multirow{3}{*}{$\begin{array}{c}\text { NMPPP } \\
53.5 \\
\end{array}$} & \multirow{3}{*}{\begin{tabular}{|c|} 
NIMPPP \\
9.0 \\
\end{tabular}} & \multirow{3}{*}{$\begin{array}{c}\mathbf{1 0 0} \\
\text { PWT (g) } \\
130.4 \\
\end{array}$} & \multirow{3}{*}{$\begin{array}{c}\begin{array}{c}\text { Shelling } \\
\text { per cent }\end{array} \\
8.3 \\
\end{array}$} & \multirow{3}{*}{$\begin{array}{c}100 \mathrm{KWT} \\
\begin{array}{c}(\mathrm{g}) \\
\end{array} \\
9.7\end{array}$} & \multirow{3}{*}{$\begin{array}{c}\text { SMK } \\
\\
2.1\end{array}$} & \multirow{3}{*}{$\begin{array}{c}\begin{array}{c}\text { DHY } \\
(\mathrm{g})\end{array} \\
55.5\end{array}$} & \multirow{3}{*}{$\begin{array}{c}\text { PYPP } \\
\text { (g) } \\
776.8\end{array}$} \\
\hline & & & & & \multirow{2}{*}{$\begin{array}{c}\text { SLA } \\
631.0\end{array}$} & \multirow{2}{*}{$\begin{array}{c}\text { SCMR } \\
4.6\end{array}$} & & & & & & & & \\
\hline Varia & Genotypic & & & & & & & & & & & & & \\
\hline nce & Phenotypic & 36.0 & 3.4 & 3.3 & 1410.9 & 7.5 & 507.1 & 13.2 & 265.9 & 14.9 & 31.9 & 11.3 & 127.3 & 913.3 \\
\hline \multirow{2}{*}{$\begin{array}{c}\text { Coeffi } \\
\text { cient } \\
\text { of } \\
\text { variati } \\
\text { on } \\
\end{array}$} & GCV & 18.3 & 27.7 & 80.9 & 11.9 & 4.9 & 36.1 & 75.4 & 13.9 & 4.3 & 8.761 & 1.6 & 26.4 & 53.9 \\
\hline & PCV & 18.7 & 31.2 & 92.4 & 17.8 & 6.3 & 111.0 & 91.3 & 19.9 & 5.7 & 15.9 & 3.7 & 39.9 & 58.4 \\
\hline \multicolumn{2}{|c|}{$\begin{array}{c}\text { Heritability } \\
\text { (Broad Sense) }\end{array}$} & 95.9 & 78.6 & 76.6 & 44.7 & 60.9 & 94.8 & 68.2 & 49.0 & 55.3 & 30.2 & 18.9 & 43.6 & 85.0 \\
\hline \multicolumn{2}{|c|}{$\begin{array}{c}\text { Genetic } \\
\text { advancement }\end{array}$} & 15.2 & 3.8 & 3.6 & 44.3 & 4.4 & 6.3 & 6.5 & 21.1 & 5.7 & 4.5 & 1.7 & 13.0 & 67.4 \\
\hline \multicolumn{2}{|c|}{$\begin{array}{c}\text { Genetic } \\
\text { advancement as per } \\
\text { cent of mean (GAM) }\end{array}$} & 47.4 & 64.7 & 186.9 & 21.0 & 10.1 & 30.9 & 164.3 & 25.8 & 8.4 & 12.7 & 1.9 & 45.9 & 13.2 \\
\hline \multicolumn{2}{|c|}{ Mean } & 32.1 & 5.9 & 1.9 & 211.1 & 43.8 & 20.3 & 4.0 & 81.8 & 67.3 & 35.5 & 89.9 & 28.2 & 51.1 \\
\hline $\begin{array}{l}\text { PLHT } \\
\text { height }\end{array}$ & : Plant & \multicolumn{5}{|c|}{ NPBPP : Number of primary branches per plant } & \multicolumn{4}{|c|}{ NSBPP: Number of secondary branches per plant } & \multicolumn{4}{|c|}{ Specific leaf area } \\
\hline \multirow{2}{*}{\multicolumn{7}{|c|}{ 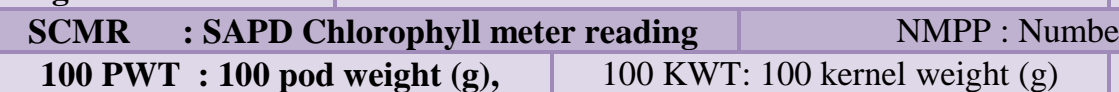 }} & rof well-fille & ed and matu & re pods per & olant & \multicolumn{4}{|c|}{ NIPPP : Number of immature pods per plant } \\
\hline & & & & & & & \multirow{2}{*}{\multicolumn{4}{|c|}{ SMK: Sound mature kernel per cent }} & \multirow{2}{*}{\multicolumn{4}{|c|}{ DHY: Dry haulms yield per plant $(\mathrm{g})$}} \\
\hline PYPP & : Pod yield per & plant $(g)$ & \multicolumn{4}{|c|}{100 KWT: 100 kernel weight $(\mathrm{g})$} & & & & & & & & \\
\hline
\end{tabular}


Table.3 Comparative statement based on estimates of different genetic parameters for water use efficiency traits, yield and yield attributes in groundnut

\begin{tabular}{|c|c|c|c|}
\hline Character & Genetic parameters & Gene effects & $\begin{array}{l}\text { Influence of } \\
\text { environment }\end{array}$ \\
\hline Plant height & \multirow{5}{*}{$\begin{array}{c}\operatorname{High~}^{2}(\mathrm{~b}) \text { and high } \\
\text { GAM }\end{array}$} & \multirow[t]{5}{*}{ Additive } & \multirow{5}{*}{ Low } \\
\hline $\begin{array}{l}\text { Number of primary branches } \\
\text { per plant }\end{array}$ & & & \\
\hline $\begin{array}{l}\text { Number of secondary branches } \\
\text { per plant }\end{array}$ & & & \\
\hline $\begin{array}{l}\text { Number of well-filled and } \\
\text { mature pods per plant }\end{array}$ & & & \\
\hline $\begin{array}{c}\text { Number of immature pods per } \\
\text { plant }\end{array}$ & & & \\
\hline 100 pod weight & \multirow{2}{*}{$\begin{array}{c}\text { Moderate } h^{2}(b) \text { and high } \\
\text { GAM }\end{array}$} & \multirow[t]{2}{*}{ Additive } & \multirow[t]{2}{*}{ Medium } \\
\hline Dry haulms yield per plant & & & \\
\hline SPAD chlorophyll meter reading & $\begin{array}{c}\operatorname{High~}^{2}(b) \text { and low } \\
\text { GAM }\end{array}$ & Non-additive & Low \\
\hline Specific leaf area & \multirow{2}{*}{$\begin{array}{l}\text { Moderate } \mathrm{h}^{2}(\mathrm{~b}) \text { and } \\
\text { moderate GAM }\end{array}$} & \multirow{2}{*}{$\begin{array}{l}\text { Both additive } \\
\text { and non } \\
\text { additive }\end{array}$} & \multirow[t]{2}{*}{ Medium } \\
\hline 100 kernel weight & & & \\
\hline Shelling per cent & $\begin{array}{c}\text { Moderate } \mathrm{h}^{2}(\mathrm{~b}) \text { and low } \\
\text { GAM }\end{array}$ & Non-additive & Low \\
\hline Sound mature kernel per cent & $\begin{array}{c}\text { Low } h^{2}(b) \text { and low } \\
\text { GAM }\end{array}$ & Non-additive & Low \\
\hline
\end{tabular}

High GCV and PCV values were observed for number of primary branches per plant, number of secondary branches per plant, number of well-filled and mature pods per plant, number of immature pods per plant, dry haulms yield per plant and pod yield per plant. Moderate GCV and PCV observed for specific leaf area, 100 pod weight and 100 kernel weight. These findings are confirmed by Khote et al., (2009), Gupta et al., (2015) and John et al., (2013). Low GCV and low PCV were noticed for sound mature kernel per cent. Korat et al., (2010) and Patil et al., (2015) were in accordance with the present findings for number of secondary branches per plant and also similar kind of high variability for number of immature pods per plant was reported by Shinde et al., (2010), Patil et al., (2015) and Hampannavar et al., (2018).
Heritability and genetic advance as per cent of mean (GAM)

GCV measure the amount of variation present in a particular character. However, it does not determine the proportion of heritable variation present in the total variation. Therefore, heritability which represents the heritable variation existing in the characters was calculated. Heritability values ranged from 18.9 per cent (sound mature kernel per cent) to 95.9 per cent (plant height). In the present study, high heritability values were recorded for the characters viz., plant height, number of primary branches per plant, number of secondary branches per plant, SPAD chlorophyll meter reading, number of wellfilled and mature pods per plant, number of immature pods per plant and pod yield per 
plant. Genetic advance as per cent of mean values ranged from 1.9 per cent (sound mature kernel per cent) to 186.9 per cent (number of secondary branches per plant). High GAM was observed for plant height, number of primary branches per plant, number of secondary branches per plant, number of wellfilled and mature pods per plant, number of immature pods per plant, 100 pod weight, dry haulms yield per plant, and pod yield per plant. Similar results were reported by Gupta et al., (2015), Bhargavi et al., (2016) and Gupta et al., (2015).

The estimates of high heritability coupled with high genetic advance as per cent of mean were observed for plant height, number of primary branches per plant, number of secondary branches per plant, number of well-filled and mature pods per plant, number of immature pods per plant and pod yield per plant indicating the importance of additive gene effects, selection for such characters may be rewarding. Similar results were Similar results were reported by Naazar et al., (2000), Padmaja et al., (2015), Sanjeevakumar Patil et al., (2015) and and Dewangan et al., (2015). The estimates of moderate heritability coupled with moderate genetic advance as per cent of mean were observed for specific leaf area and 100 kernel weight indicating the importance of additive gene effects, selection for such characters may be rewarding. Similar results were reported by John et al., (2006) and Shinde et al., (2010). High heritability and low GAM was expressed for SPAD chlorophyll meter reading whereas low heritability and low GAM was recorded for sound mature kernel per cent indicating the preponderance of non-additive gene action in inheritance of this character, hence, selection for these characters is not effective. Similar reports were reported by Korat et al., (2009), Yadav et al., (2014) and John and Reddy (2014).

High estimates of GCV, PCV, heritability and genetic advance as per cent of mean were observe for number of primary branches per plant, number of secondary branches per plant, number of well-filled and mature pods per plant, number of immature pods per plant, pod yield per plant indicating the importance of additive gene action and selection for such characters may be rewarding. In conclusion, more number of well-filled and mature pods per plant was registered by TCGS-1835. The highest pod yield per plant was recorded by TCGS-1514. High heritability coupled with high genetic advance as per cent of mean were observed for number of primary branches per plant, number of secondary branches per plant, number of well-filled and mature pods per plant and pod yield per plant indicating the importance of additive gene effects, selection for such characters may be rewarding.

\section{Acknowledgement}

This research was supported under the DSTSERB to the first author by the Department of Science and Technology - Science and Engineering Research Board, New Delhi is gratefully acknowledged.

\section{References}

Allard R W 1960 Principles of Plant Breeding John Wiley and Sons, Inc., USA Wiley International Edition pp.85.

Basu, M.S., Chunilal., Prakash C., Nautiyal., 2004. Breeding strategies to increase water use efficiency of groundnut. Groundnut Research in India, Edited by M.S.Basu and N.B. Singh. pp. 3847.

Bhargavi, G Rao, S. V., Rao, K. L. N. 2016. Genetic variability, heritability and

genetic advance of yield and related traits of Spanish bunch groundnut (Arachis hypogaea L.). Agricultural Science Digest. 36(1):60-62.

Chav Burton G W 1952 Quantitative inheritance in grass. Proceedings of sixth international grassland congress. 
1: 227-283.

Chavadhari, R. M., Kachhadia, V. H., Vachhani, J. H., Virani, M. B., 2017. Genetic variability studies in groundnut (Arachis hypogaea L.). Electronic Journal of Plant Breeding, 8(4): 1288-1292.

Dewangan, H., Jaiswal, N. K., Gabrial, M. L., Rai, P. K., 2015. Study on genetic variability in groundnut (Arachis hypogaea L.) germplasms International Journal of Science Research 5(1):1922.

Gupta, R., P., Vachhani, J. H., Kachhadia, V. H., Vaddoria, M. A., Reddy, P., 2015. Genetic variability and heritability studies in Virginia groundnut (Arachis hypogaea L.). Electronic Journal Plant Breeding, 6(1):253-256.

Hampannavar, M.R., Khan, H., Temburne, B.V., Janila, P., Amaregouda, A., 2018. Genetic variability, correlation and path analysis studies for yield and yield attributes in groundnut (Arachis $\begin{array}{lll}\text { hypogaea } & \text { L.). Journal of }\end{array}$ Pharmacognosy and Phytochemistry. 7(1): 870-874.

John K and Vasanthi R P 2006 Heterosis in six single crosses of groundnut Legume Research 29 (4): 262-265.

John, K., Vasanthi, R.P., Sireesha, K., Giridhara Krishna, T., 2013. Genetic variability studies in different advanced breeding genotypes of Spanish bunch groundnut (Arachis hypogaea L.). International Journal of Applied Bio.Pharma. Tech., 4(2):213217.

John, K., Reddy, P.R., 2014. Variability, heritability and genetic advances for water use efficiency traits in groundnut (Arachis hypogaea L.). International Journal of Current Science. 13:1-5.

Johnson H W Robinson H F and Comstock R E 1955 Estimates of genetic and environmental variability in soybean.
Agronomy Journal 47: 413-418.

Khote, A.C., Bendale, V.W., Bhave, S.G. and Patil, P.P (2009). Genetic variability heritability and genetic advance in some exotic genotypes of groundnut (Arachis hypogaea L.). Crop Res., 37 (1,2 \&3):186-191.

Korat, V. P., Pithia, M. S., Savaliya, J. J., Pansuriya, A. G. and Sodavadiya, P. R., 2009. Studies on genetic variability in different genotypes of groundnut (Arachis hypogaea L.). Legume Research. 32(3):224-226

Korat, V.P., Pithia, M.S., Savaliya, J.J., Pansuriya, A.G. Sodavadiya, P.R., 2010. Studies on characters association and path analysis for seed yield and its components in groundnut (Arachis hypogaea L.). Legume Research. 33(3): 211-216.

Ladole, M.Y., Wakode, M.M., and Deshmuhkh, S.N (2009). Genetic variability and character association studies for yield and yield contributing traits in groundnut (Arachis hypogaea L.). J. Oilseeds Res., 26 (special Issue): 123-125.

Naazar, A., Mallik, S.N., Bashir, K. and Mirza, M.Y. 2000. Genetic variability, heritability and correlation studies in groundnut. J. Agri., 16: 533-536.

Nandini, C., savithramma, D.L., Naresh Babu, N., 2011. Genetic variability for surrogate traits of water use efficiency in F8 recombinent inbred lines of the cross NRCG $12568 \mathrm{x}$ NRCG-12326 in groundnut (Arachis hypogaea L.). Electronic. Journal of Plant Breeding. 2(4): 555-558.

Padmaja D, Eswari K. B., Brahmeswara Rao M.V, Shiva Prasad G. (2015). Genetic variability studies in F2 population of Groundnut (Arachis hypogeaea L.). Helix Vol. 2: 668-672.

Patel, J.D., Desai, N.C., Kodappuiiy, V.C., Vaghela, K.O., 2009. Genetic 
variability, correlation and path analysis in moth bean. GAU Research Journal. 34(2): 83-87.

Patil, S., Shivanna, S., Irappa, B.M., Shweta., 2015. Genetic variability and character association studies for yield and yield attributing components in groundnut. (Arachis hypogaea L.). International Journal of Recent Scientific Research. 6(6): 4568-4570.

Sadiq, S.M., Saleem, M., Igbal, J., 1986. Genetic variation and selection in hexaploid triticale. Proceedings of the International Triticale Symposium. Darvey, N.L. Edition. Australian institute of agricultural science. 182185.

Sanjeevakumar Patil, Shivanna, S., Irappa B. M. and Shweta (2015). Genetic variability and character association studies for yield and yield attributing components in groundnut (Arachis hypogeae L.). International Journal of
Recent Scientific Research 6(6): 45684570.

Shinde, P.P., Khanpara, M.D., Jivani, L.L.., Vachhani, J.H and Kachhadia, V.H al. (2010). Genetic variability in Virginia bunch groundnut (Arachis hypogaea L.).Plant Archives, 10(2): 703-706.

Wadikar, P.B., Dake, A.D., Chavan, M.V., Thorat, G.S., 2018. Character association and variability studies of yield and its attributing character in groundnut (Arachis hypogea L.). International Journal of Current Microbiology and Applied Sciences. 6: 924-929.

Yadav, S.R., Rathod, A.H., Sindhe, A.S., Patade, S.S., Patil, C.N., Vaghela, P.O., 2014. Genetic variability and divergence Studies in groundnut (Arachis hypogea L.). International Journal of Agricultural Sciences. 10 (2): 691-694.

\section{How to cite this article:}

John, K., M. V. Madhavi Santhoshi and Rajasekhar, P. 2019. Study of Genetic Parameters for Water Use Efficiency Traits, Yield and Yield Attributes in Groundnut (Arachis hypogaea L.). Int.J.Curr.Microbiol.App.Sci. 8(12): 1511-1520. doi: https://doi.org/10.20546/ijcmas.2019.812.181 